\title{
Fatty Acids and Associated Cardiovascular Risk
}

\author{
Caroline Le Goff $^{1}$, Jean-François Kaux ${ }^{2}$, Ludovic Leroy ${ }^{1}$, Joël Pincemail ${ }^{3}$, Jean-Paul Chapelle ${ }^{1}$, \\ Etienne Cavalier ${ }^{1}$
}

${ }^{1}$ Department of Clinical Chemistry, University and University Hospital of Liege, Liege, Belgium; ${ }^{2}$ Department of Clinical Sciences, University and University Hospital of Liege, Liege, Belgium; ${ }^{3}$ CREDEC, Department of Cardiovascular Surgery, University Hospital of Liege, Liege, Belgium.

Email: c.legoff@chu.ulg.ac.be

Received July $9^{\text {th }}, 2013$; revised August $9^{\text {th }}, 2013$; accepted August $16^{\text {th }}, 2013$

Copyright (C) 2013 Caroline Le Goff et al. This is an open access article distributed under the Creative Commons Attribution License, which permits unrestricted use, distribution, and reproduction in any medium, provided the original work is properly cited.

\begin{abstract}
Introduction: A fatty acid (FA) is a carboxylic acid with a long aliphatic chain, which is either saturated or unsaturated. Recently, the role of FA and particularly omega- 3 and -6 has emerged as cardiovascular risk factor in the literature. The aim of our study was to establish reference values for these FA and to compare them with data obtained in a population of acute myocardial infarction (AMI) patients. Materials and methods: Hundred thirty five healthy subjects $(59.38 \pm$ 27.12 yo, 75 men) were selected as reference population. We also evaluated FA in thirty three patients (55 \pm 9 yo, 23 men) admitted in the Emergency Department of our Institution for AMI. The fasting whole blood was drawn in vacutainer containing EDTA. Before analysis, samples were washed and transmethylated. We performed the quantification of different FA by gas chromatography associated with flame ionization detector (GCFID). Results: We obtained results in control healthy patients to be used as reference values. In the AMI group, levels of omega-6 were significantly higher $(\mathrm{p}<0.05)$ for $\mathrm{C} 18: 2 \mathrm{n} 6$ and $\mathrm{C} 18: 3 \mathrm{n} 6$ than the reference population and omega-3 values were significantly lower $(\mathrm{p}<0.01)$ compared to reference value for $\mathrm{C} 22: 6 \mathrm{n} 3$. The omega-3 index was lower and the ratio omega-6/omega-3 was higher in AMI group compared to reference values. Conclusions: We have established reference value for FA and have compared these values with the results obtained in AMI population. FA determination is a new tool we are able to use and to process in our laboratory which can help the clinician to screen patients with the highest cardiovascular risks because of the implication of FA in the etiopathogeny of atherosclerosis.
\end{abstract}

Keywords: Fatty Acids; Acute Myocardial Infarction; Gas Chromatography

\section{Introduction}

A fatty acid (FA) is a carboxylic acid with a long aliphatic chain. This chain can either be saturated or unsaturated. Most naturally occurring FA have a chain of 4 to 28 carbon atoms. FA are produced by hydrolysis of the ester linkages in a fat or biological oil (both of which are triglycerides), with the removal of glycerol. There are many families of FA: "essential FA" with omega-3, omega-6, omega-7, omega-9, "saturated" FA (SFA) and "unsaturated" (cis and trans) FA. Table 1 shows the fatty acids with their common name, the International Union of Pure and Applied Chemists (IUPAC) name and the formula [1]. For many years, research has focused on the involvement of fatty acids and their repercussions on the cardiovascular system.

The implication of FA, particularly, omega- 3 and -6 in different diseases has been widely published in literature [2-9]. SFA, abundantly found in our diet, participate in the development of certain metabolic abnormalities such as insulin resistance or atherosclerosis $[10,11]$. However, all SFA have different metabolic effects. For example, palmitic acid (which consists of $50 \%$ palm oil versus a maximum of $17 \%$ for other oils such as peanut oil), unlike other SFA such as stearic acid, is a potent inhibitor of the intracellular pathway for insulin in some tissues such as skeletal muscle $[10,12]$. SFA are also considered as pro-inflammatory agents because they stimulate the inflammatory response in different cell types, such as adipocytes, particularly during the postprandial phase $[12$, 13]. Finally, this class of fatty acids probably contributes to the development of atherosclerotic plaques because it causes increased plasma concentrations of LDL-cholesterol [12]. All of this knowledge means that the current intake of SFA in western food, and in particular, palmitic acid, is a key player in the expansion of certain metabolic diseases such as type 2 diabetes, cardiovascular disease 
Table 1. Fatty acids with their common name, the International Union of Pure and Applied Chemists (IUPAC) name and the formula.

\begin{tabular}{|c|c|c|c|}
\hline Symbol & Chemical structure & Acid's common name & IUPAC name \\
\hline \multicolumn{4}{|c|}{ Saturated fatty acid } \\
\hline $\mathrm{C} 14: 0$ & $\mathrm{CH}_{3}\left(\mathrm{CH}_{2}\right)_{12} \mathrm{COOH}$ & Myristic acid & tétradécanoïque \\
\hline $\mathrm{C} 15: 0$ & $\mathrm{CH}_{3}(\mathrm{CH} 2)_{13} \mathrm{COOH}$ & Pentadecanoic acid & Pentadecanoic \\
\hline $\mathrm{C} 16: 0$ & $\mathrm{CH}_{3}(\mathrm{CH} 2)_{14} \mathrm{COOH}$ & Palmitic acid & hexadecanoic \\
\hline $\mathrm{C} 17: 0$ & $\mathrm{CH}_{3}(\mathrm{CH} 2)_{15} \mathrm{COOH}$ & Margaric acid & heptadecanoic \\
\hline C18:0 & $\mathrm{CH}_{3}(\mathrm{CH} 2)_{16} \mathrm{COOH}$ & Stearic acid & octadecanoic \\
\hline $\mathrm{C} 20: 0$ & $\mathrm{CH}_{3}(\mathrm{CH} 2)_{18} \mathrm{COOH}$ & Arachidic acid & eicosanoic \\
\hline \multicolumn{4}{|c|}{ Unsatured fatty acid $\omega-3$} \\
\hline C18: $3 \omega-3$ & $\mathrm{CH}_{3}\left(\mathrm{CH}_{2} \mathrm{CH}=\mathrm{CH}\right)_{3}\left(\mathrm{CH}_{2}\right)_{7} \mathrm{COOH}$ & $\alpha$-linolenic acid & cis,cis,cis-9,12,15-octadécatrienoic \\
\hline $\mathrm{C} 20: 5 \omega-3$ & $\mathrm{CH}_{3} \mathrm{CH}_{2}\left(\mathrm{CH}=\mathrm{CHCH}_{2}\right)_{4} \mathrm{CH}=\mathrm{CH}\left(\mathrm{CH}_{2}\right)_{3} \mathrm{COOH}$ & Eicosapentaenoic acid & $\begin{array}{l}\text { cis,cis,cis,cis,cis-5,8,11,14, } \\
\text { 17-eicosapentaenoic }\end{array}$ \\
\hline $\mathrm{C} 22: 5 \omega-3$ & $\mathrm{CH}_{3} \mathrm{CH}_{2} \mathrm{CH}=\mathrm{CH}\left(\mathrm{CH}_{2}\right)_{2} \mathrm{CH}=\mathrm{CHCH}_{2}\left(\mathrm{CH}=\mathrm{CH}\left(\mathrm{CH}_{2}\right)_{2}\right)_{3} \mathrm{COOH}$ & Docosapentaenoic acid & $\begin{array}{l}\text { cis,cis,cis,cis,cis-4,8,12,15, } \\
\text { 19-docosapentaenoic }\end{array}$ \\
\hline $\mathrm{C} 22: 6 \omega-3$ & $\mathrm{CH}_{3} \mathrm{CH}_{2}\left(\mathrm{CH}=\mathrm{CHCH}_{2}\right)_{5} \mathrm{CH}=\mathrm{CH}\left(\mathrm{CH}_{2}\right)_{2} \mathrm{COOH}$ & Docosahexaenoic acid & $\begin{array}{c}\text { cis,cis,cis,cis,cis,cis-4,7,10,13,16, } \\
\text { 19-docosahexaenoic }\end{array}$ \\
\hline \multicolumn{4}{|c|}{ Unsatured fatty acid $\omega-6$} \\
\hline C18: $2 \omega-6$ & $\mathrm{CH}_{3}\left(\mathrm{CH}_{2}\right)_{4} \mathrm{CH}=\mathrm{CHCH}_{2} \mathrm{CH}=\mathrm{CH}\left(\mathrm{CH}_{2}\right)_{7} \mathrm{COOH}$ & Linoleic acid & cis,cis-9,12-octadecadienoic \\
\hline C18: $3 \omega-6$ & $\mathrm{CH}_{3}\left(\mathrm{CH}_{2}\right)_{3}\left(\mathrm{CH}_{2} \mathrm{CH}=\mathrm{CH}\right)_{3}\left(\mathrm{CH}_{2}\right)_{4} \mathrm{COOH}$ & $\gamma$-linolenic acid & cis,cis,cis-6,9,12-octadecatrienoic \\
\hline $\mathrm{C} 20: 3 \omega-6$ & $\mathrm{CH}_{3}\left(\mathrm{CH}_{2}\right)_{4}\left(\mathrm{CH}=\mathrm{CHCH}_{2}\right)_{3}\left(\mathrm{CH}_{2}\right)_{5} \mathrm{COOH}$ & di-homo- $\gamma$-linolenic acid & cis,cis,cis-8,11,14-eïcosatrienoic \\
\hline C20: $4 \omega-6$ & $\mathrm{CH}_{3}\left(\mathrm{CH}_{2}\right)_{4}\left(\mathrm{CH}=\mathrm{CHCH}_{2}\right)_{3} \mathrm{CH}=\mathrm{CH}\left(\mathrm{CH}_{2}\right)_{3} \mathrm{COOH}$ & Arachidonic acid & $\begin{array}{l}\text { cis,cis,cis,cis-5,8,11, } \\
\text { 14-eicosatetraenoic }\end{array}$ \\
\hline \multicolumn{4}{|c|}{ Others unsatured fatty acid } \\
\hline C16: $1 \omega-7$ & $\mathrm{CH}_{3}\left(\mathrm{CH}_{2}\right)_{5} \mathrm{CH}=\mathrm{CH}\left(\mathrm{CH}_{2}\right)_{7} \mathrm{COOH}$ & Palmitoleic acid & cis-9-hexadécénoic \\
\hline C18: $1 \omega-9$ & $\mathrm{CH}_{3}\left(\mathrm{CH}_{2}\right)_{7} \mathrm{CH}=\mathrm{CH}\left(\mathrm{CH}_{2}\right)_{7} \mathrm{COOH}$ & Oléic acid & cis-9-octadécénoic \\
\hline C20: $1 \omega-9$ & $\mathrm{CH}_{3}\left(\mathrm{CH}_{2}\right)_{7} \mathrm{CH}=\mathrm{CH}\left(\mathrm{CH}_{2}\right)_{9} \mathrm{COOH}$ & Gondoic acid & cis-9-eicosénoic \\
\hline \multicolumn{4}{|c|}{ Trans unsatured fatty acid } \\
\hline C18: $1 \omega-9$ & $\mathrm{CH}_{3}\left(\mathrm{CH}_{2}\right)_{7} \mathrm{CH}=\mathrm{CH}\left(\mathrm{CH}_{2}\right)_{7} \mathrm{COOH}$ & Elaidic acid & trans-9-octadecenoic \\
\hline $\mathrm{C} 18: 2 \omega-6$ & $\mathrm{CH}_{3}\left(\mathrm{CH}_{2}\right)_{4} \mathrm{CH}=\mathrm{CHCH}=\mathrm{CH}\left(\mathrm{CH}_{2}\right)_{8} \mathrm{COOH}$ & Linolelaidic acid & trans,cis-10,12-octadecadienoic \\
\hline
\end{tabular}

or metabolic syndrome [8,14]. Dietary long-chain, polyunsaturated fatty acid (PUFA) also benefit the blood vessel wall by enhancing cell membrane fluidity and regulating membrane receptors [15].

Hundreds of epidemiologic studies, either of mechanisms of action, or experimental in animals have shown that dietary intake of omega-3 FA presented anti atherosclerotic potential [16-24]. The role of FA in the atherosclerossis process was already discussed by Sinclain in 1956 in the Lancet [25].

Some authors have demonstrated that the protective effect of omega-3 PUFAs in sudden cardiac death which was most often due to ventricular arrhythmia $[5,26]$. However, in patients with implantable cardioverter defibrillators and cardiac failure, no benefit of supplementation with omega-3 could be established [27]. The erythrocyte fatty acid profile is modified; the omega-3 PUFA concentrations are elevated and predict the risk of ventricular arrhythmia. These results highlight an altered cardiac metabolism in patients with heart failure and may have clinical implications for early identification of subjects at high risk [28].

In general, prospective epidemiological studies have shown a relationship between intake of trans fatty acids 
and increased morbidity and mortality from cardiovascular disease in Europe and North America [29,30]. The incomes of trans fatty acids compared to the intake of cis fatty acids, increase levels of LDL-cholesterol, triglycerides, lipoprotein Lp (a) and decrease levels of HDLcholesterol and the actual particle size of LDL-cholesterol. Each point may increase the risk of coronary heart disease [31].

An important concept in the field of fatty acids is the balance omega-6/omega-3. An ideal relationship for dietary intake would be 1:1 but it is rather around the ratio of 15:1, linked to deficiency of omega-3 PUFA intakes. The increase in the proportion of omega-6 PUFA is considered as a risk factor for many diseases such as heart disease, inflammatory, autoimmune and various cancers [2]. Freije compared the fatty acid composition of erythrocyte membranes in healthy patients with those of patients with coronary heart disease in Bahrain [2]. The results mainly showed a low level of docosahexaenoic acid which increases the risk of coronary heart disease. Moreover, there was also an increased ratio of omega-6/ omega-3. An omega-3 index decrease (which is the sum of the percentages of docosahexaenoic acid and eicosapentaenoic acid), was also observed in these patients [3].

The aim of our study was to establish reference values for these FA and to compare the results obtained with data observed in patients with acute myocardial infarction (AMI) seen the protector role of PUFA particularly, omega-3, and the implication of SFA in the development of atherosclerosis [32].

\section{Materials and Methods}

Hundred thirty five healthy subjects $(59.38 \pm 27.12$ yo, 75 men) were selected as reference population (patient without cardiac antecedent or diabetes). We also evaluated FA in thirty three patients ( $55 \pm 9$ yo, 23 men) admitted in the Emergency Department of our Institution for AMI. All patients gave their informed consent.

Fasting whole blood samples were drawn in vacutainer tubes containing EDTA. One millilitre of whole blood was centrifuged at $3500 \mathrm{rpm}$ for $5 \mathrm{~min}$ at $4^{\circ} \mathrm{C}$. Plasma was carefully separated and the red blood cells (RBC) pellet was washed three times with equal volumes of standard saline. All the washings were carried out at $4^{\circ} \mathrm{C}$. The white viscous material after each washing was carefully removed to minimize contamination by non-erythrocytic cells. The samples were finally stored at $-20^{\circ} \mathrm{C}$ until analyzed (personal data).

Before analysis, the samples were washed and an extraction was done.

Briefly, $0.3 \mathrm{ml}$ packed RBCs were placed in a $5 \mathrm{ml}$ clean glass vial with $100 \mu 1$ of C28 (Internal Standard). RBCs were then treated with $2 \mathrm{ml}$ of methanolic-
$\mathrm{HCl} .95 \% / 5 \%$. The vials were sealed and incubated at $80^{\circ} \mathrm{C}$ for $2 \mathrm{~h}$. After incubation the mixture was treated with $5 \mathrm{ml}$ of hexane and centrifuged at $3500 \mathrm{rpm}$ for 10 min at room temperature using a swinging rotor. The top aqueous layer comprised mainly of methylated fatty acids. Hexane mixture was then carefully collected in a separate vial. This step was repeated three times and all extractions were pooled. The methylated-fatty acids hexane mixture was then completely dried at $55^{\circ} \mathrm{C}$ under nitrogen. Methylated fatty acids were dissolved in $100 \mu \mathrm{l}$ hexane and $1 \mu \mathrm{l}$ was identified and quantified by gas chromatography with flame ionization detector (GC/FID) performed on a Shimadzu GC2010, using a capillary column SP-2380 of $30 \mathrm{~mm} \times 0.25 \mathrm{~mm} \times 0.20 \mu \mathrm{m}$ dimensions (Supelco). A FID was used with an oven temperature set at $250^{\circ} \mathrm{C}$. The temperature of the injector was $250^{\circ} \mathrm{C}$ whereas the detector was set at $260^{\circ} \mathrm{C}$.

The quantification of FA is realized according to the calibration curve that we have established with standards for all peaks that we must identify.

First, we expressed the results in $\mathrm{mg} / \mathrm{L}$ and after we chose to express results in percent (\%) from the total of results. The sum of the FA found in a patient equals $100 \%$ and with a simple calculation we expressed them in $\%$ in relation to the sum of FA.

For the statistical analysis, we used an independent sample T-test with the statistical software Medcalc 9.1 (Mariakerk, Belgium).

\section{Results}

Figure 1 shows the chromatographic profile of the different FA analyzed. The Table 2 presents the comparison of the results observed in AMI and in healthy subjects (reference values).

We obtained differences between AMI group and our healthy population.

In AMI, the levels of omega- 6 were significantly higher $(\mathrm{p}<0.05)$ for $\mathrm{C} 18: 3 \mathrm{n} 6$. The level of omega-3 was lower in comparison with reference values but not significantly. We also calculated the omega- 3 index and the ratio omega-6/omega-3. The omega-3 index was significantly lower $(\mathrm{p}<0.0001)$ in AMI compared to the reference value and the omega-6/omega-3 ratio was significantly higher $(p<0.005)$ in AMI than in reference patients. The sum of SFA was also significantly higher in AMI group $(p<0.05)$. We also noted a significantly difference $(p<0.005)$ between both types of patients for C18:1n9.

\section{Discussion}

The incidence of cardiovascular disease is different between the countries and increases from Southern to the Northern countries (Europe) [33,34]. 


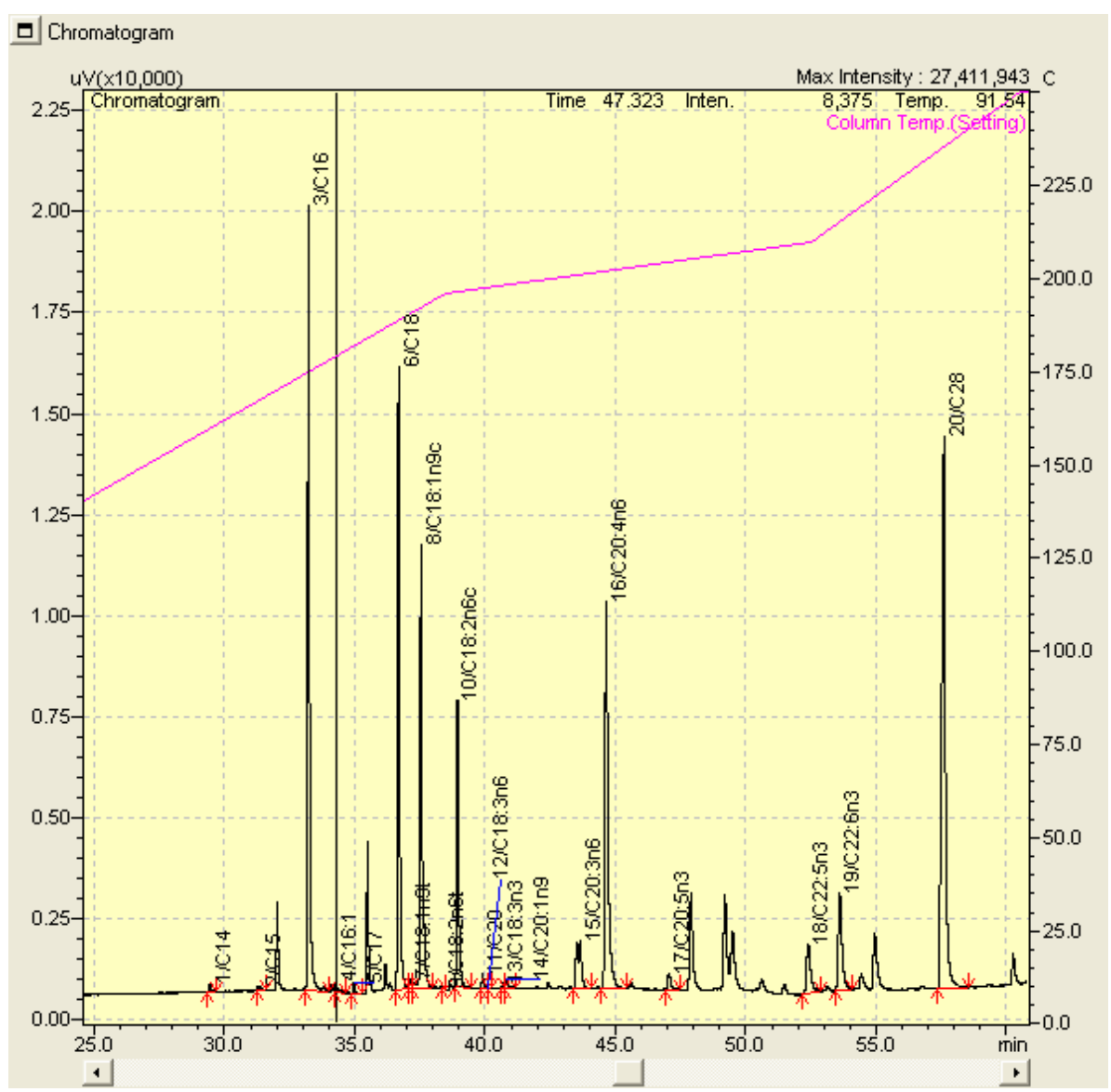

Figure 1. Example of a chromatographic profile of the different FA analyzed by gas chromatography in a healthy subject.

Cardiovascular diseases are the first cause of mortality and morbidity in the developped countries. They are the world's largest killers, claiming 17.1 million lives a year [35]. This incidence has increased with time. One explanation is probably found in changes of life style: aging, tobacco use, unhealthy diet, stress, physical inactivity and harmful use of alcohol increase the risk of heart attacks and strokes [35]. Atherosclerosis initiation and early progression is almost invariability a result of abnormal interactions between circulating oxidized lipids and blood vessel walls. Endothelial dysfunction has been linked to diverse vascular abnormalities like atherosclerosis. The first detectable stage in atherosclerosis is a slightly raised, fatty "streak" in the arterial wall. Among Western populations, these can be found in most individuals beginning as early as the teenage years [15]. In Northern of Europe, it is well known that people do not follow the Mediterranean diet, which has long been celebrated as the gold standard of healthy diet for its favourable impact on the prevention of chronic diseases, promotion of greater longevity and quality of life [36].

We have studied AMI patients because they are at risk of a second myocardial infarction due to their cardiovascular risk phenotype. Moreover, the implication of SFA and PUFA in the etiopathogeny of atherosclerosis is well known. We found thus very interesting to be able to make the quantification of these different FA to achieve on the dietary prevention (supplementation in omega-3, decrease of intake of SFA...).

For the SFA, we observed a statistical increase between AMI and control subjects. These results are in accordance with Walrand et al. study [12], which explained that SFA was a key player in the expansion of cardiovascular disease. This class of fatty acids is most likely involved in the development of atherosclerosis probably due to the induced increasing of plasma concentrations of LDL-cholesterol. However, one of the limitations of our study is without any doubt the age difference between both patient groups as well as daily hygiene which we were able to define with our control group but not with the AMI group.

Our study also showed a statistically significant difference between the percentages of oleic acid (C18: 1n $9 c)$ in the 2 groups. This increase in oleic acid has also been observed in the study of Harris et al. [4] who studied the lipid profile and erythrocytic plasma after myocardial infarction. It must be said that this fatty acid is often considered beneficial as it benefits from the posi- 
Table 2. Comparison between AMI and reference group for FA (FA in \%). p-values in red are statistically significative $(\mathbf{p}<0.05)$.

\begin{tabular}{cccc}
\hline & $\begin{array}{c}\text { FA AMI } \% \\
(\mathrm{n}=33)\end{array}$ & $\begin{array}{c}\text { FA reference } \% \\
(\mathrm{n}=135)\end{array}$ & p-value \\
\hline C14 & $1.00 \pm 0.21$ & $0.9 \pm 0.19$ & 0.024 \\
C15 & $0.34 \pm 0.07$ & $0.37 \pm 0.15$ & $<0.001$ \\
C16 & $25.45 \pm 1.51$ & $31.05 \pm 7.7$ & $<0.001$ \\
C16: 1 & $0.56 \pm 0.21$ & $0.52 \pm 0.23$ & 0.329 \\
C17 & $0.42 \pm 0.09$ & $0.41 \pm 0.07$ & 0.085 \\
C18 & $20.53 \pm 1.35$ & $20.16 \pm 1.56$ & 0.342 \\
C18: $1 \omega 9 \mathrm{t}$ & $0.23 \pm 0.13$ & $0.19 \pm 0.09$ & 0.003 \\
C18: $1 \omega 9 \mathrm{c}$ & $15.43 \pm 1.38$ & $14.68 \pm 1.03$ & 0.005 \\
C18: $2 \omega 6 \mathrm{t}$ & $0.07 \pm 0.02$ & $0.07 \pm 0.04$ & 0.513 \\
$\mathrm{C} 18: 2 \omega 6 \mathrm{c}$ & $9.15 \pm 1.34$ & $9.64 \pm 0.89$ & 0.043 \\
C20 & $0.54 \pm 0.09$ & $0.57 \pm 0.08$ & 0.063 \\
$\mathrm{C} 18: 3 \omega 6$ & $0.11 \pm 0.04$ & $0.08 \pm 0.02$ & 0.034 \\
$\mathrm{C} 18: 3 \omega 3$ & $0.22 \pm 0.04$ & $0.24 \pm 0.06$ & 0.212 \\
$\mathrm{C} 20: 1 \omega 9$ & $0.27 \pm 0.08$ & $0.26 \pm 0.05$ & 0.553 \\
$\mathrm{C} 20: 3 \omega 6$ & $2.14 \pm 0.50$ & $2.26 \pm 0.51$ & 0.301 \\
$\mathrm{C} 20: 4 \omega 6$ & $15.45 \pm 1.54$ & $14.99 \pm 1.15$ & 0.112 \\
$\mathrm{C} 20: 5 \omega 3$ & $0.78 \pm 0.26$ & $0.72 \pm 0.34$ & 0.079 \\
$\mathrm{C} 22: 5 \omega 3$ & $1.94 \pm 0.34$ & $2.00 \pm 1.08$ & 0.749 \\
$\mathrm{C} 22: 6 \omega 3$ & $5.37 \pm 1.36$ & $6.28 \pm 3.04$ & 0.094 \\
$\mathrm{Sum}$ of SFA & $48.27 \pm 1.38$ & $47.57 \pm 1.35$ & 0.022 \\
$\omega 6 / \omega 3$ & $3.39 \pm 0.86$ & $2.86 \pm 0.58$ & 0.001 \\
$\omega 3$ index & $6.15 \pm 1.51$ & $7.60 \pm 1.62$ & $<0.001$ \\
\hline & & &
\end{tabular}

tive image of olive oil, containing $70 \%$ oleic acid, and no less favourable than the Mediterranean diet. However, a portion of beneficial effects in olive oil on endothelial functions, inflammation, platelet aggregation, and perhaps even on HDL cholesterol is the lipid fraction of the olive oil [37].

In regards to trans fatty acids some statistically significant difference $(p<0.005)$ was observed between the 2 groups although many articles $[31,38]$ show the harmful effects related to the consumption of trans fatty acids on the development of cardiovascular risk factors. Indeed, they are proven to increase levels of LDL-cholesterol, triglycerides, lipoprotein $\mathrm{Lp}$ (a), and lower levels of HDL-cholesterol as well as particle size of LDL-cholesterol. It is for all these reasons that the political authorities try to regulate the possible content of trans fat in food.
In this study, we observed differences between the two studied groups in terms of docosahexaenoic acid (C22: 6 n3), omega-6/omega-3 ratio and the omega-index, but also a significant difference for linoleic acid (C18: $2 \mathrm{n} 6 \mathrm{c})$. These differences are consistent with both studies [3,39], which highlighted the same differences. However in the Freije study, the percentage of $\mathrm{C} 22: 6 \mathrm{n} 3$ decreased from $2.81 \%$ to $0.41 \%$ and the $\omega 3$ index from $3.14 \%$ to $0.64 \%$ in control subjects and AMI patients [2]. These results were obtained in the kingdom of Bahrain and the authors believe that these low values of $\mathrm{C} 22: 6 \mathrm{n} 3$ could be due to very low omega-3 fatty acids in fish inhabiting nearby waters [2]. The attempts to corroborate the higher results were obtained.

\section{Conclusion}

We have established reference values for FA implicated in different pathologies like cardiovascular diseases. This is a new tool we are able to use in our laboratory which can help clinicians to highlight and target patients with a higher cardiovascular risks. The clinicians could then supplement the patients with, for example, omega-3 to reduce the risk of developing cardiac diseases because of the implication of FA in the etiopathogeny of atherosclerosis.

\section{REFERENCES}

[1] A. D. McNaught and A. Wilkinson, "IUPAC Compendium of Chemical Terminology," 2nd Edition, Blackwell Science, Oxford, 1997.

[2] A. Freije, "Fatty Acid Profile of the Erythrocyte Membranes of Healthy Bahraini Citizens in Comparison with Coronary Heart Disease Patients," Journal of Oleo Science, Vol. 58, No. 7, 2009, pp. 379-388. doi: $10.5650 /$ jos. 58.379

[3] G. Durand and J. L. Beaudeux, "Biochimie Médicale: Marqueurs Actuels et Perspectives," Lavoisier, Paris, 2008.

[4] W. S. Harris and C. Von Schacky, "The Omega-3 Index: A New Risk Factor for Death from Coronary Heart Disease?" Preventive Medicine, Vol. 39, No. 1, 2004, pp. 212-220. doi:10.1016/j.ypmed.2004.02.030

[5] C. M. Albert, H. Campos, M. J. Stampfer, P. M. Ridker, J. E. Manson, W. C. Willett, et al., "Blood Levels of Long-Chain n-3 Fatty Acids and the Risk of Sudden Death," The New England Journal of Medicine, Vol. 346, No. 15, 2002, pp. 1113-1138. doi:10.1056/NEJMoa012918

[6] F. Paganelli, J. M. Maixent, M. J. Duran, R. Parhizgar, G. Pieroni and S. Sennoune, "Altered Erythrocyte n-3 Fatty Acids in Mediterranean Patients with Coronary Artery Disease," International Journal of Cardiology, Vol. 78, No. 1, 2001, pp. 27-32. doi:10.1016/S0167-5273(00)00442-3

[7] H. Rupp, D. Wagner, T. Rupp, L. M. Schulte and B. 
Maisch, "Risk Stratification by the 'EPA + DHA Level' and the 'EPA/AA Ratio' Focus on Anti-Inflammatory and Antiarrhythmogenic Effects of Long-Chain Omega-3 Fatty Acids," Herz, Vol. 29, No. 7, 2004, pp. 673-685. doi:10.1007/s00059-004-2602-4

[8] A. M. Hodge, D. R. English, K. O’Dea, A. J. Sinclair, M. Makrides, R. A. Gibson, et al., "Plasma Phospholipid and Dietary Fatty Acids as Predictors of Type 2 Diabetes: Interpreting the Role of Linoleic Acid," The American Journal of Clinical Nutrition, Vol. 86, No. 1, 2007, pp. 189-197.

[9] G. Mamalakis, M. Kiriakakis, G. Tsibinos, E. Jansen, H. Cremers, C. Strien, et al., "Lack of an Association of Depression with n-3 Polyunsaturated Fatty Acids in Adipose Tissue and Serum Phospholipids in Healthy Adults," Pharmacology Biochemistry and Behavior, Vol. 89, No. 1, 2008, pp. 6-10. doi:10.1016/j.pbb.2007.10.015

[10] S. M. Hirabara, R. Curi and P. Maechler, "Saturated Fatty Acid-Induced Insulin Resistance Is Associated with Mitochondrial Dysfunction in Skeletal Muscle Cells," Journal of Cellular Physiology, Vol. 222, No. 1, 2010, pp. 187-194. doi:10.1002/jep.21936

[11] J. Lovergrove, L. Brady, S. Lesauvage, A. M. Minihane and C. Williams, "Platelet Membrane Phospholipid Fatty Acids Are Weakly Associated with Markers of Insulin Resistance and Some CVD Risk Factors," ISSFAL2008.

[12] S. Walrand, F. Fisch and J. M. Bourre, "Do Saturated Fatty Acids Have the Same Metabolic Effect?" Nutrition Clinique et Metabolisme, Vol. 24, No. 2, 2010, pp. 63-75. doi:10.1016/j.nupar.2010.02.003

[13] S. Sierra, F. Lara-Villoslada, M. Comalada, M. Olivares and J. Xaus, "Dietary Eicosapentaenoic Acid and Docosahexaenoic Acid Equally Incorporate as Decosahexaenoic Acid but Differ in Inflammatory Effects," Nutrition, Vol. 24, No. 3, 2008, pp. 245-254. doi:10.1016/j.nut.2007.11.005

[14] R. B. Moore and S. H. Appel, "Methylation of Erythrocyte Membrane Phospholipids in Patients with Myotonic and Duchenne Muscular Dystrophy," Experimental Neurology, Vol. 70, No. 2, 1980, pp. 380-391. doi:10.1016/0014-4886(80)90035-7

[15] P. R. Kidd, "Cell Membranes, Endothelia, and Atherosclerosis-The Importance of Dietary Fatty Acid Balance," Alternative Medicine Review, Vol. 1, No. 3, 1996, pp. 148-165.

[16] C. Von Schacky, "Prophylaxis of Atherosclerosis with Marine Omega-3 Fatty Acids. A Comprehensive Strategy," Annals of Internal Medicine, Vol. 107, No. 6, 1987, pp. 890-899. doi:10.7326/0003-4819-107-6-890

[17] T. A. Dolecek, "Epidemiological Evidence of Relationships between Dietary Polyunsaturated Fatty Acids and Mortality in the Multiple Risk Factor Intervention Trial," Proceedings of the Society for Experimental Biology and Medicine, Vol. 200, No. 2, 1992, pp. 177-182. doi:10.3181/00379727-200-43413

[18] C. M. Albert, C. H. Hennekens, C. J. O'Donnell, U. A. Ajani, V. J. Carey, W. C. Willett, et al., "Fish Consumption and Risk of Sudden Cardiac Death," JAMA, Vol. 279, No. 1, 1998, pp. 23-28. doi:10.1001/jama.279.1.23
[19] D. S. Siscovick, T. E. Raghunathan, I. King, S. Weinmann, K. G. Wicklund, J. Albright, et al., "Dietary Intake and Cell Membrane Levels of Long-Chain n-3 Polyunsaturated Fatty Acids and the Risk of Primary Cardiac Arrest," JAMA, Vol. 274, No. 17, 1995, pp. 1363-1367. doi:10.1001/jama.1995.03530170043030

[20] M. L. Daviglus, J. Stamler, A. J. Orencia, A. R. Dyer, K. Liu, P. Greenland, et al., "Fish Consumption and the 30-Year Risk of Fatal Myocardial Infarction," The New England Journal of Medicine, Vol. 336, No. 15, 1997, pp. 1046-1053. doi:10.1056/NEJM199704103361502

[21] J. Dyerberg and H. O. Bang, "Haemostatic Function and Platelet Polyunsaturated Fatty Acids in Eskimos," Lancet, Vol. 2, No. 8140, 1979, pp. 433-435. doi:10.1016/S0140-6736(79)91490-9

[22] W. E. Kaminski, E. Jendraschak, R. Kiefl and C. von Schacky, "Dietary Omega-3 Fatty Acids Lower Levels of Platelet-Derived Growth Factor mRNA in Human Mononuclear Cells," Blood, Vol. 81, No. 7, 1993, pp. 18711879 .

[23] S. Endres and C. von Schacky, "n-3 Polyunsaturated Fatty Acids and Human Cytokine Synthesis," Current Opinion in Lipidology, Vol. 7, No. 1, 1996, pp. 48-52. doi:10.1097/00041433-199602000-00011

[24] C. Von Schacky, "Cardiovascular Effects of n-3 Fatty Acids," In: J. C. Frölich and C. Von Schacky, Ed., Fish, Fish Oil, and Human Health, Zuckschwerdt Verlag, Munich, 1992, pp. 167-178.

[25] H. M. Sinclair, "Deficiency of Essential Fatty Acids and Atherosclerosis, Etcetera," Lancet, Vol. 270, No. 6919, 1956, pp. 381-383.

[26] M. Wilhelm, R. Tobias, F. Asskali, R. Kraehner, S. Kuly, L. Klinghammer, et al., "Red Blood Cell Omega-3 Fatty Acids and the Risk of Ventricular Arrhythmias in Patients with Heart Failure," American Heart Journal, Vol. 155, No. 6, 2008, pp. 971-977. doi:10.1016/j.ahj.2007.11.045

[27] P. Saravanan, N. C. Davidson, E. B. Schmidt and P. C. Calder, "Cardiovascular Effects of Marine Omega-3 Fatty Acids," Lancet, Vol. 376, No. 9740, 2010, pp. 540-50. doi:10.1016/S0140-6736(10)60445-X

[28] F. B. Hu, M. J. Stampfer, J. E. Manson, E. Rimm, G. A. Colditz, B. A. Rosner, et al., "Dietary Fat Intake and the Risk of Coronary Heart Disease in Women," The New England Journal of Medicine, Vol. 337, No. 21, 1997, pp. 1491-1499. doi:10.1056/NEJM199711203372102

[29] W. C. Willett, M. J. Stampfer, J. E. Manson, G. A. Colditz, F. E. Speizer, B. A. Rosner, et al., "Intake of Trans Fatty Acids and Risk of Coronary Heart Disease among Women," Lancet, Vol. 341, No. 8845, 1993, pp. 581-585. doi:10.1016/0140-6736(93)90350-P

[30] D. Mozaffarian, "Trans Fatty Acids-Effects on Systemic Inflammation and Endothelial Function," Atherosclerosis Supplements, Vol. 7, No. 2, 2006, pp. 29-32. doi:10.1016/j.atherosclerosissup.2006.04.007

[31] A. P. Simopoulos and L. G. Cleland, "Omega-6/Omega-3 Essential Fatty Acid Ratio: The Scientific Evidence," Karger AG, Basel, 2003.

[32] Q. Sun, J. Ma, H. Campos, S. E. Hankinson and F. B. Hu, 
"Comparison between Plasma and Erythrocyte Fatty Acid Content as Biomarkers of Fatty Acid Intake in US Women," The American Journal of Clinical Nutrition, Vol. 86, No. 1, 2007, pp. 74-81.

[33] W. C. Smith and H. Tunstall-Pedoe, "European Regional Variation in Cardiovascular Mortality," British Medical Bulletin, Vol. 40, No. 4, 1984, pp. 374-379.

[34] J. Muller-Nordhorn, S. Binting, S. Roll and S. N. Willich, "An Update on Regional Variation in Cardiovascular Mortality within Europe," European Heart Journal, Vol. 29, No. 10, 2008, pp. 1316-1326. doi:10.1093/eurheartj/ehm604

[35] World Health Organization, "Prevention of Cardiovascular Disease : Guidelines for Assessment and Management of Total Cardiovascular Risk," World Health Organization, Geneva, 2007.

[36] J. B. Brill, "The Mediterranean Diet and Your Health," American Journal of Lifestyle Medicine, Vol. 3, No. 1,
2009, pp. 44-56. doi:10.1177/1559827608325476

[37] D. R. Morgan, L. J. Dixon, C. G. Hanratty, N. El-Sherbeeny, P. B. Hamilton, L. T. McGrath, et al., "Effects of Dietary Omega-3 Fatty Acid Supplementation on Endothelium-Dependent Vasodilation in Patients with Chronic Heart Failure," American Journal of Cardiology, Vol. 97, No. 4, 2006, pp. 547-551. doi:10.1016/j.amjcard.2005.08.075

[38] Y. Park, J. Lim, Y. Kwon and J. Lee, "Correlation of Erythrocyte Fatty Acid Composition and Dietary Intakes with Markers of Atherosclerosis in Patients with Myocardial Infarction," Nutrition Research, Vol. 29, No. 6, 2009, pp. 391-396. doi:10.1016/j.nutres.2009.05.010

[39] D. Mozaffarian, T. Pischon, S. E. Hankinson, N. Rifai, K. Joshipura, W. C. Willett, et al., "Trans-Fatty Acid Intake and Systemic Inflammation among Women," Circulation, Vol. 109, No. 7, 2004, p. 195. 